\title{
Preliminary Trial of Cover Cropping and Weed Control for Organic Rice
}

\section{Gena R. Mahato1, Anna McClung2, Sixte Ntamatungiro1, Surendra Singh ${ }^{3}$, Meghnath Pokharel4, Vince Wiley ${ }^{1}$, Bihu Huang ${ }^{*}$}

\author{
${ }^{1}$ Department of Agriculture, University of Arkansas at Pine Bluff, Pine Bluff, USA \\ ${ }^{2}$ Dale Bumpers National Rice Research Center, Stuttgart, USA \\ ${ }^{3}$ University of Tennessee, Knoxville, USA \\ ${ }^{4}$ Kansas State University, Manhattan, USA \\ Email: ^huangb@uapb.edu
}

How to cite this paper: Mahato, G.R., McClung, A., Ntamatungiro, S., Singh, S., Pokharel, M., Wiley, V. and Huang, B. (2017) Preliminary Trial of Cover Cropping and Weed Control for Organic Rice. American Journal of Plant Sciences, 8, 2758-2768.

https://doi.org/10.4236/ajps.2017.811186

Received: September 12, 2017

Accepted: October 20, 2017

Published: October 23, 2017

Copyright $\odot 2017$ by authors and Scientific Research Publishing Inc. This work is licensed under the Creative Commons Attribution International License (CC BY 4.0).

http://creativecommons.org/licenses/by/4.0/

\begin{abstract}
The experiment site at UAPB agronomy farm was left undisturbed for several years for organic rice experiment. Soil samples taken in September 2015 showed that the experiment site was deficient with plant nutrients (NPK). Therefore, an organic fertilizer, Nature (8-5-5) was applied before planting mixture of crimson clover and winter wheat as cover crop in fall 2015. Biomass samples taken from the cover cropped land (CCL) and fallow land (FL) resulted in decrease in weed biomass by $33.36 \%$ and increase in total biomass by $46.78 \%$ in CCL than FL. Cover crops were incorporated one month before the rice sowing in June 2016. Fifteen rice cultivars were experimented for weed competition under water seeding cultivation method. Water seeding method was not effective to control the weeds as weeds dominated most of the rice plots since seedling stage. However, two rice cultivars namely Jasmine 85 and Rondo showed strong weed competition due to higher plant stand and better seedling establishment.
\end{abstract}

\section{Keywords}

Organic Farming, Water Seeding, Flooding, Plastic Mulch Covering, Weed Pressure, Varietal Selection, Biomass

\section{Introduction}

Organic rice has started to gain popularity as the safer and healthier alternative, especially in developed countries [1]. Demand for organic rice is increasing with up to 50,000 acres produced in the USA [2]. In US, organic rice farmland has 
increased almost six times since 1995 to now [3]. However, current organic rice production in US is unable to meet the current market demand. Organic rice buyers in the US are importing large percentages of their rice from Cambodia [4].

Major challenges in organic rice production include nutrient optimization, weed management and variety selection [5]. Weed competition is one of the prime yield limiting biotic constraints in rice [6]. Uncontrolled weed can reduce rice yield by $44 \%$ to $94 \%$ [7]. Weeds even can cause total crop failure [8]. Through selection of weed competitive cultivars, the weed emergence and its subsequent growth can be suppressed [9]. Thus, varietal selection can be alternative to weed management in organic rice. Likewise, flooding and cover cropping are tools in integrated weed management for organic rice production. Water seeding of rice is widely practiced in USA [7]. In water seeded rice, the field is continuously flooded [10]. Water seeding takes advantage of that by establishing an early water covering to suppress weeds, but continuous flooding in water seeded rice culture encourages aquatic weeds, and when continuous flood is not maintained, it encourages semiaquatic weeds [7].

Cover crops provide numerous environmental and weed suppression benefits [11]. The physical and allelopathic effects caused by cover crops residue can be used to suppress the emergence of weed and reduce weed growth [12]. Cover crop mixtures provide more effective weed suppression relative to monoculture cover crops [13] because of complementarity function of cover crop species [14]. Cover crop mixtures of cereals and legumes are expected to accumulate more biomass than single-species counterparts at similar seeding rates [14].

\section{Material and Methods}

The experiment site was planted with winter wheat and crimson clover as cover crop in fall 2015 (Figures 1-3). Above ground cover crop biomass were sampled in April, 2016. Each biomass samples were taken within one meter square area

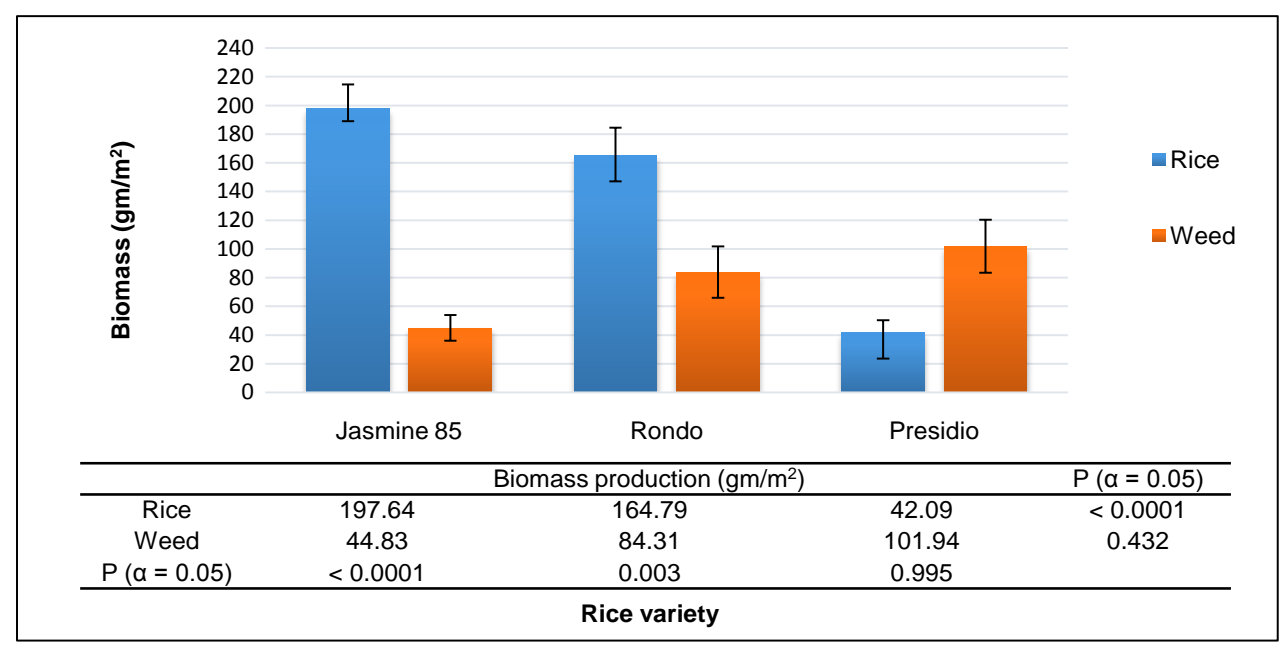

Figure 1. Biomass of selected rice cultivars and weed biomass in respective rice cultivars. 


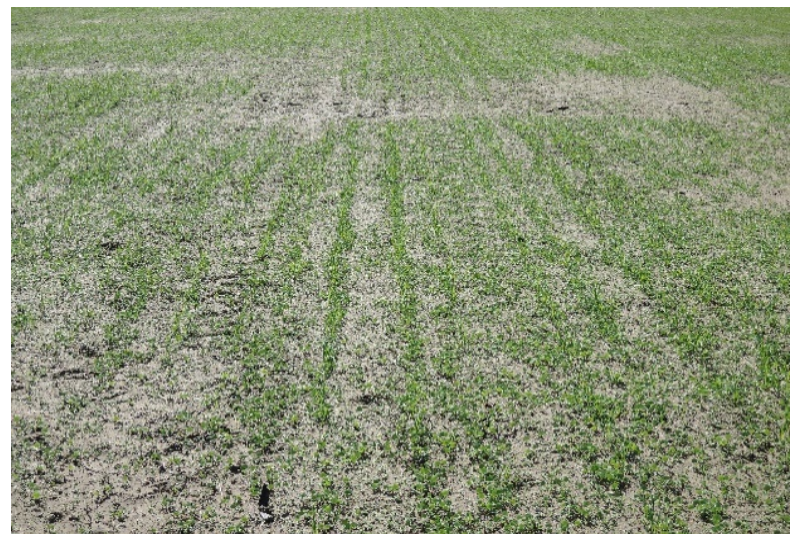

Figure 2. Crimson clover and Winter wheat in the winter.

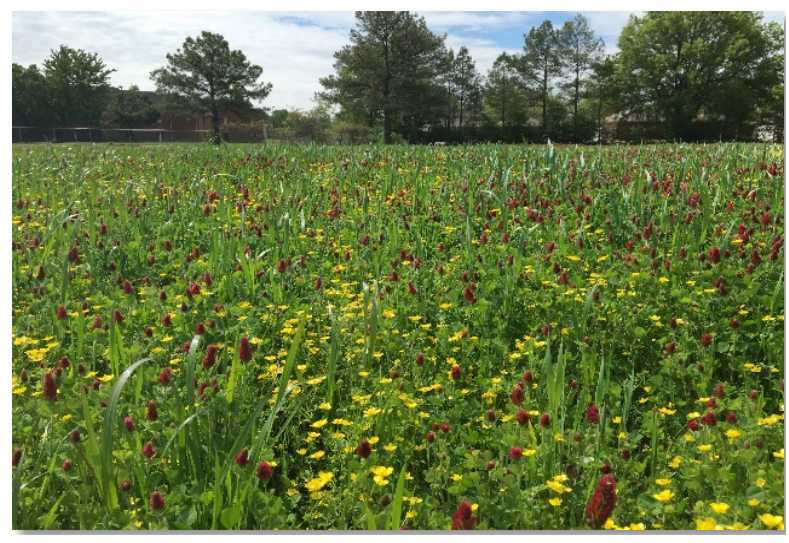

Figure 3. Crimson clover and Winter wheat before harvest.

with six samples each from cover cropped Land (CCL) and fallow land (FL) (Figure 4). Cover crop and weed species were separated from each samples and dried biomass of cover crop and weed species were measured (Figure 5). Cover crop was incorporated one month before rice sowing.

In June 2016, fifteen rice cultivars were planted using randomized complete block design with four replications. Water seeded rice and flooding were used as method to control weeds. Seeds were put in the individual cloth bags for varieties and replications then soaked in the water overnight and kept in moisture for two days before planting (Figure 6 and Figure 7). Soaked seeds were uniformly spread into each small plot (Figure 8 and Figure 9). After third week of rice sowing, photographs of each rice plots was taken twice a week for visual scoring of plant stand rating and plot weed pressure of each rice plots and this process was continued till eighth week after rice sowing. Plant stand rating and plot weed pressure measured on each week was computed as average score for each rice cultivar (Figure 10). Plant stand rating was measured at scale of 1 - 10 score, where 1 represents $10 \%$ plant stand and 10 represents $100 \%$ plant stand in a plot. Likewise, Plot weed pressure was measured at scale of 1 - 10 score, where 1 represents $10 \%$ plot weed pressure and 10 represents $100 \%$ weed pressure.

Three rice varieties Jasmine 85, Rondo and Presidio were selected for rice 


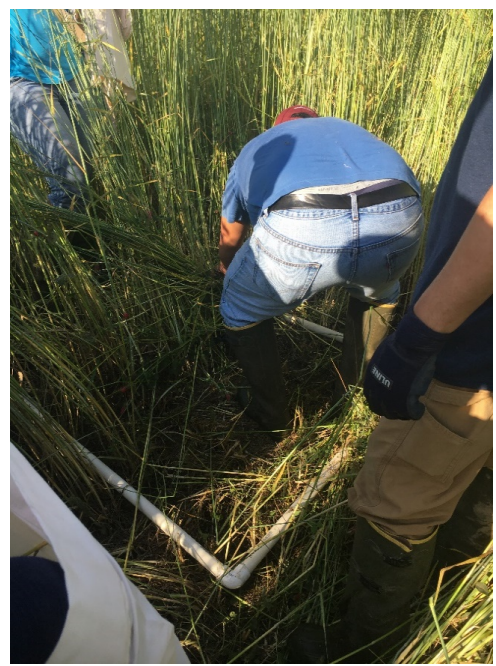

Figure 4. Harvesting one square meter cover crops and weeds.
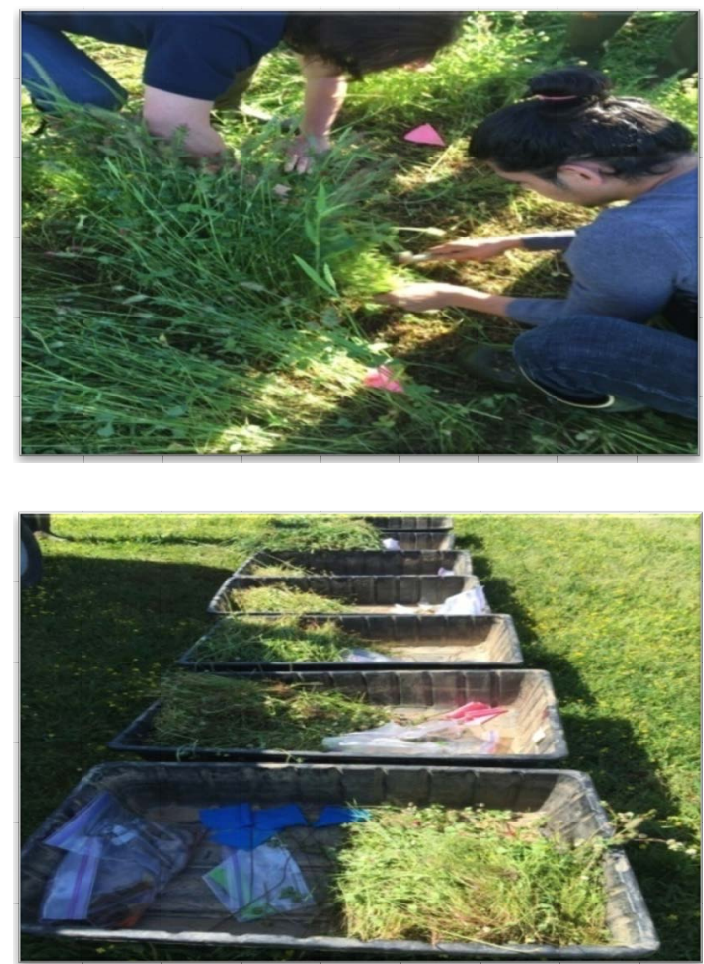

Figure 5. Separating cover crops and weeds.

biomass sampling 80 days after sowing. Biomass samples were taken from three quadrats each with $50 \mathrm{~cm} \times 50 \mathrm{~cm}$ within rice plots. Dry biomass of rice and weed in respective rice plots were measured.

\section{Results}

\subsection{Biomass Production from Cover Crop Planting}

Total biomass yield was $483.33 \mathrm{~g} / \mathrm{m}^{2}$ for Cover Crop Land (CCL) and $329.17 \mathrm{~g} / \mathrm{m}^{2}$ 


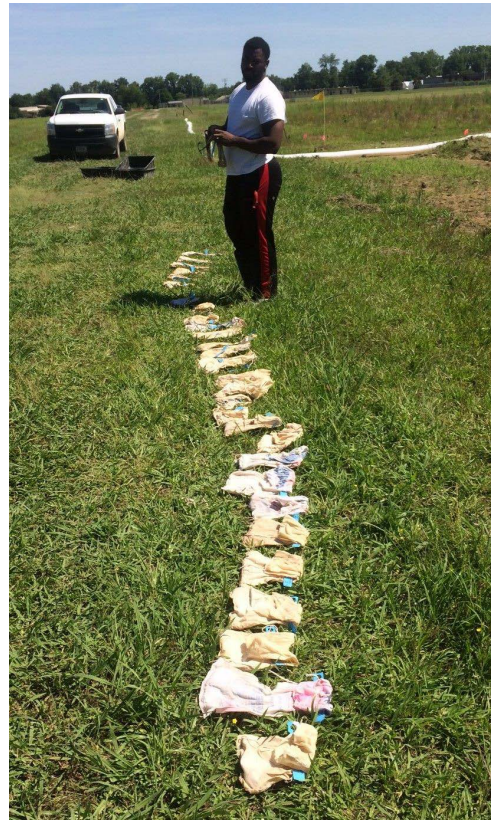

Figure 6. Each cloth bag contains weighed out seed for each plot. Bags were soaked in water and then drained to allow piping of the seed.

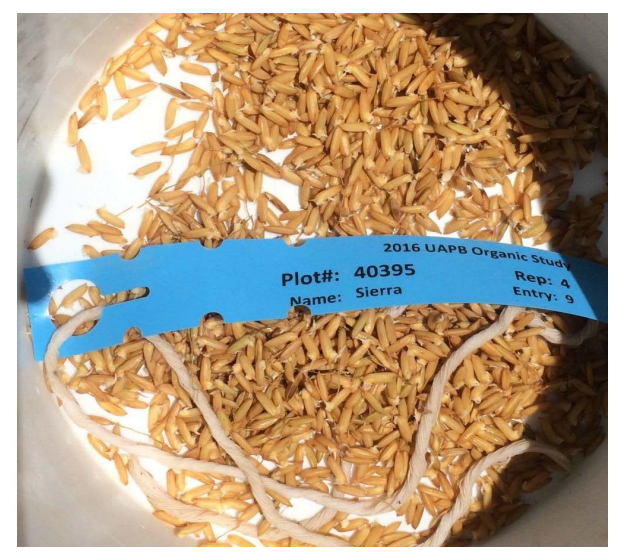

Figure 7. Bucket containing piped seed of variety for water seeding.

for fallow land (FL), and cover cropping resulted $46.78 \%$ increase in total biomass production. Total weeds yield $195.33 \mathrm{~g} / \mathrm{m}^{2}$ for CCL and $242.83 \mathrm{~g} / \mathrm{m}^{2}$ for FL. Cover cropping reduced weed biomass by $33.36 \%$ (Table 1). Of the mixture of cover crop, crimson clover and winter wheat accounted for 59.59\% of total biomass in cover cropping land whereas, white clover and crimson clover appeared naturally in fallow land which accounted for $26.33 \%$ total biomass (Table 1 ).

\subsection{Plant Stand Rating and Plot Weed Pressure Score of Rice Cultivars}

Out of the fifteen rice varieties, Jasmine 85 and Rondo showed substantial weed competition. Plot weed pressure of Jasmine 85 and Rondo was found comparatively 


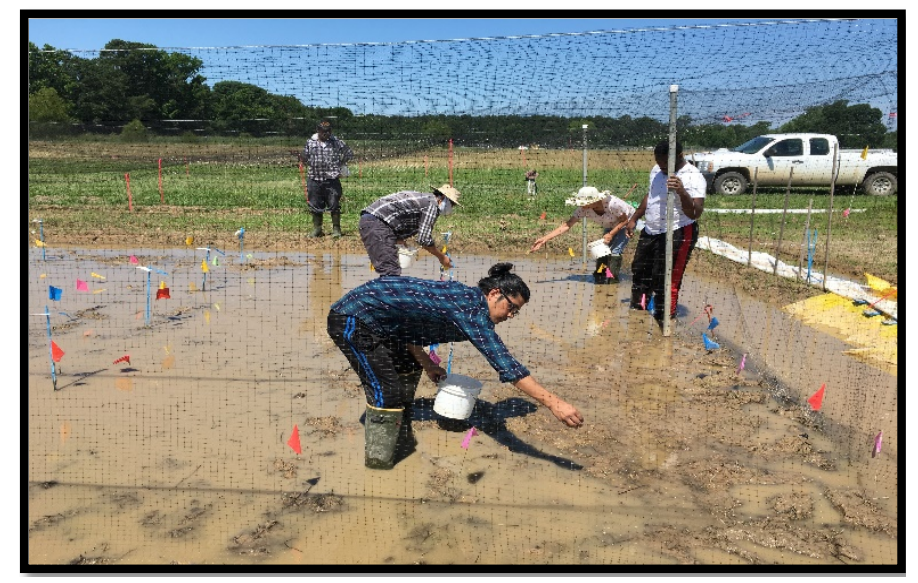

Figure 8. Water seeding of yield plots. Perimeter of each plot marked with flags.

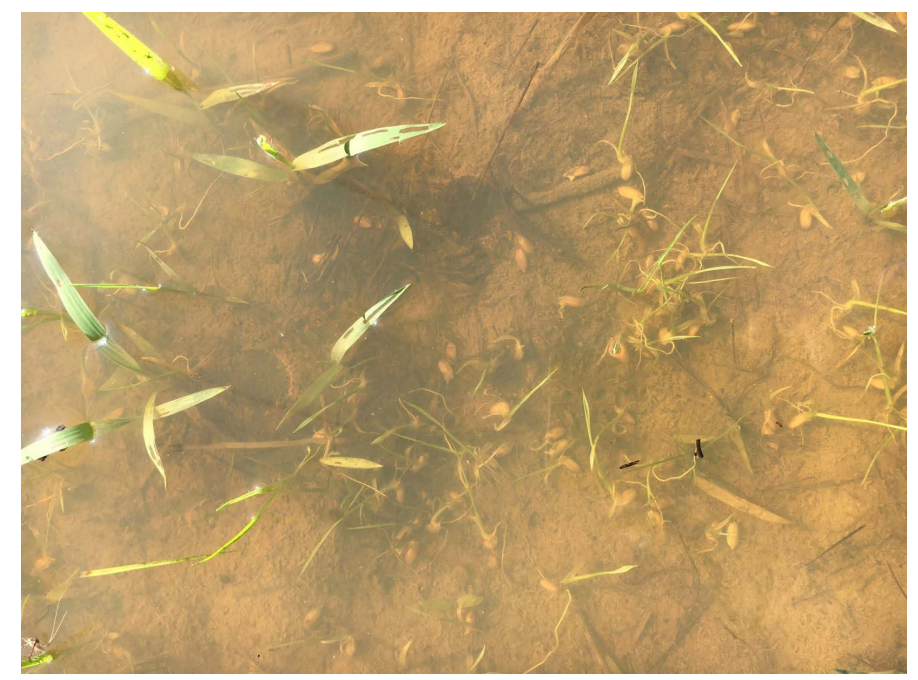

Figure 9. Sprouted seed taking root. Field is kept flooded to control the also present grass and nuts edges.

lower, 5.75 and 5.0 respectively at rating scale of $0-10$ score (Table 2), than other rice varieties. Also, the plant stand rating for Jasmine 85 and Rondo was found higher, 7.75 and 8.75 respectively at rating scale of 0 - 10 score (Table 2), as compared to other rice varieties. Ark 061 and PI 312777 are allelopathic in nature but these two rice varieties were found to be very less weed competitive with high plot weed pressure, 9.0 in Ark 061 and 9.50 in PI 312777 and low plant stand rating, 2.75 in Ark 061 and 3.50 in PI 312777 (Table 2).

\subsection{Biomass Production of Selected Rice Cultivars}

The biomass sampling of selected rice varieties resulted in significantly $(\mathrm{p}=$ 0.05 ) higher biomass production from more weed competitive varieties, Jasmine 85 and Rondo than conventional variety Presidio, one of the representative of less weed competitive rice varieties. Likewise, the weed biomass production in respective plots of Jasmine 85 was found significantly lower $(p=0.05)$ than 


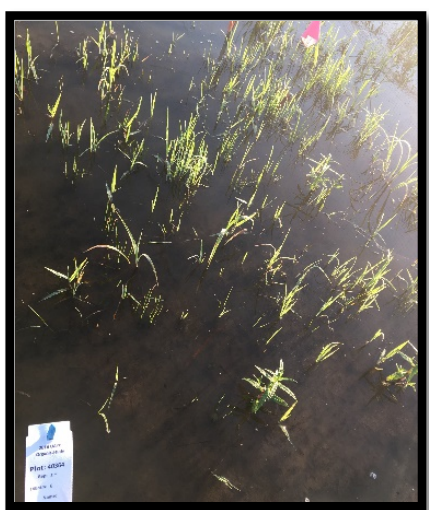

Variety-Ark 061, PSR-1

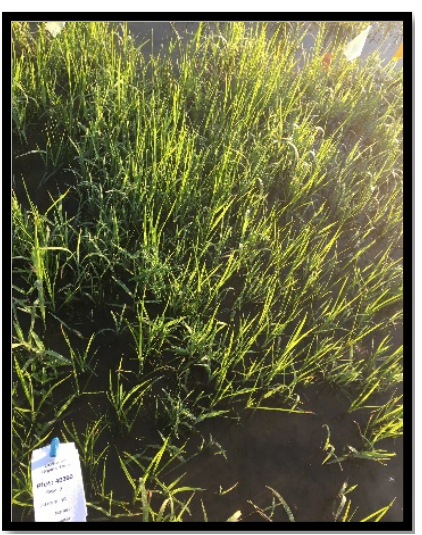

Variety-Jupiter, PSR-6

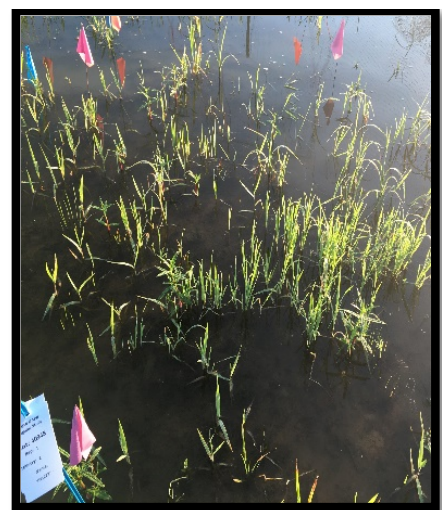

Variety-PI312777, PSR-3

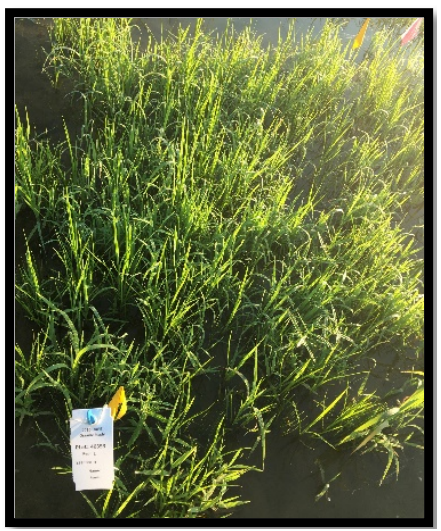

Variety-Rondo, PSR-8

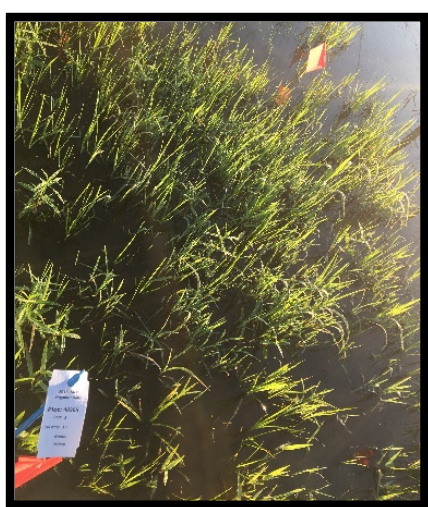

Variety-Delrose, PSR-5

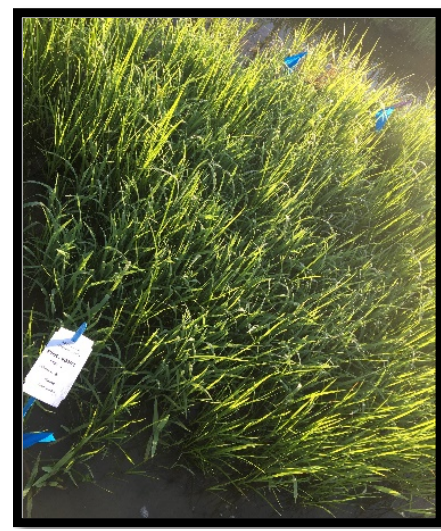

Variety-Jasmine 85, PSR-9

Figure 10. Visual coring of Plant stand rating (PSR) of rice cultivars.

Table 1. Cover crop and weed biomass production from cover cropping and fallow land.

\begin{tabular}{ccccccc}
\hline & \multicolumn{3}{c}{ Biomass production $\left(\mathrm{gm} / \mathrm{m}^{2}\right)$} & \multicolumn{2}{c}{ Biomass \% } \\
\cline { 2 - 4 } Treatment & Total biomass & Weed & \multicolumn{2}{c}{ Cover crop } & Weed & Cover crop \\
\cline { 3 - 6 } & & & Clover & Winter wheat & & \\
\hline CCL & 483.33 & 195.33 & 228.5 & 59.5 & 40.41 & 59.59 \\
FL & 329.17 & 242.83 & 86.33 & & 73.77 & 26.23 \\
$\mathrm{P}(\alpha=0.05)$ & 0.0390 & 0.836 & 0.037 & & \\
\hline
\end{tabular}

Presidio. But the weed biomass obtained from the plots of Rondo and Presidio was not significantly different. This indicates that Rondo is more tolerant to weeds and able to grow despite of incidence of weeds.

\section{Discussion}

Cover crops have higher impact on weed biomass [15]. In this experiment, mixtures of crimson clover and winter wheat produced considerable reduction in weed biomass and increase in total biomass. Crimson clover as a leguminous cover crop provides more organic matter to soil [11] and atmospherically fix $\mathrm{Ni}$ trogen $(77-111 \mathrm{~kg} \mathrm{~N} / \mathrm{ha})$ to succeeding crop [16]. Cover crops including 
Table 2. Plant stand rating and plot weed pressure rating of rice varieties experimented in 2016.

\begin{tabular}{ccc}
\hline Rice variety & Plant stand rating $(0-10)$ & Plot weed pressure $(0-10)$ \\
\hline Ark 061 & 2.75 & 9.0 \\
Cocodrie & 2.50 & 9.50 \\
Delrose & 4.0 & 7.25 \\
Jasmine 85 & 7.75 & 5.75 \\
Jazzman & 2.0 & 8.25 \\
Jazzman 2 & 4.0 & 9.25 \\
Jupiter & 2.75 & 8.75 \\
Mermentau & 4.75 & 8.5 \\
PI 312777 & 3.5 & 9.50 \\
Presidio & 4.0 & 9.75 \\
Rex & 5.5 & 8.75 \\
Rondo & 8.75 & 5.0 \\
Roy J & 6.25 & 8.0 \\
Sierra & 1.25 & 10.0 \\
XL 753 & 4.75 & 8.75 \\
LSD ( $\alpha=0.05)$ & 3.53 & 3.21 \\
\hline
\end{tabular}

crimson clover as mixture or monoculture can suppress weeds and improve yield, primarily due to biomass effects [14]. Residue from winter annual cover crop provides early-season weed suppression [17]. Likewise, legume cover crop provides weed suppression during active cover growth and just after cover crop termination [18]. On the other hand, because of high C:N ratio in residues of cereal cover crops, the residue of winter wheat after termination can offer increased weed suppression for a relatively longer period of time [19] as cover crop residues left on soil surface suppress weed emergence and growth due to reduced light transmittance and daily soil temperature [20] enabling lower initial competition on following crop. This cover cropping trial is limited to study on effect of mixture of crimson clover and winter wheat on weed biomass during growing season and question about effects of this cover crop on weed suppression and crop yield in subsequent organic rice remain unanswered. However, mixture of crimson clover and winter wheat could be successfully be used as integrated weed control alternative in organic farms.

The use of water seeding in this study to suppress weeds and produce economic yield for organic rice was not successful. Dominantly Cyperus esculentus, Cyperus iria and Echinochloa crusgalli germinated together with rice seedling. These weeds have rapid growth, and they are highly competitive and adapted to aquatic condition [7]. Particularly weeds adapted to aquatic condition become more difficult to control by continuous flooding when they are established. 
However, Moody et al. [21] reported that weed population density and total dry weight per unit area decrease as water depth increases. On the other hand, Sahid and Hossain [22] reported that emergence and survival of some weeds remain unaffected by a flooding depth of $15 \mathrm{~cm}$. Water management is crucial in successful weed control in water seeded rice because flood water affects the density, vigor, and uniformity of rice stands, and severity of weed competition [7]. This research in following years will be focused on other alternative methods such as use of plastic mulch covering for weed management in organic rice production.

The higher weed suppression potential of Jasmine 85 and Rondo observed in the experiment is largely due to higher plant stand and better seedling establishment than other rice varieties. Main characteristics imparting weed competitiveness to rice include selection of cultivars, seeding vigor, early and faster seedling establishment, shoot-root characteristics and self-supportive allelopathy [9]. Oluyemi, A.T. [23] reported that Jasmine 85 grows rapidly, gives high yield, carries good resistance to pests in Southern United States and also suppresses the growth of weeds in surrounding area. Likewise, Gealy and Yan [24] reported that Rondo has high yield potential and ability to suppress or tolerate rice pests, including weeds.

\section{Conclusion}

Cover cropping is benefit for weed control and increase rice biomass in the organic rice production. Stronger weed competition varieties, Jasmine 85 and Rondo rice cultivars were found to have substantial weed competition capacity. These two high yielding rice varieties are grown organically in Texas. Therefore, Jasmine 85 and Rondo can be a better varietal choice for organic rice growers.

\section{References}

[1] Bagchi, T.B., Ghosh, A., Kumar, U., Chattopadhyay, K., Sanghamitra, P., Ray, S. and Sharma, S. (2016) Comparison of Nutritional and Physicochemical Quality of Rice Under Organic and Standard Production Systems. Cereal Chemistry, 93, 435-443.

[2] Dou, F., Xin-Gen, Z., McClung, A., McClung, A., Liu, G. and Landry, K. (2012) Developing Sustainable Management Practices for Organic Rice Production. Texas Experiment Station Field Day Handout, 15-16.

[3] The Organic Center (2015) Sustainable and Profitable Strategies for IPM in Southern Organic Rice.

https://www.organic-center.org/our-projects/sustainable-and-profitable-strategies-f or-ipm-in-southern-organic-rice/

[4] Keller, R. (2013) US Imports Large Volume of Organic Rice. http://www.agprofessional.com/news/US-imports-large-volume-of-organic-rice-20 1976661.html

[5] Dou, F., Zhou, X., McClung, A., Storlien, J., Lang, Y., Torbert, A., Hons, F., Wards, B., Kresovich, S. and Wight, J. (2014) Cover Crop, Soil Amendments, and Variety Effects on Organic Rice Production in Texas. Proceedings of 35 th Rice Tech. Work. Group Meet., New Orleans, LA, 18-21 February 2014, p. 141.

[6] Sangeetha, C., Velayutham, A., Thavaprakaash, N. and Chinnusamy, C. (2015) Crop Establishment and Weed Management Effects on Rice Productivity and Weed 
Dynamics. Indian Journal of Weed Science, 47, 6-10.

[7] Ampong-Nyarko, K. and De Datta, S.K. (1991) A Handbook for Weed Control in Rice. IRRI, Manilla.

[8] Islam, M.J. and Molla, H.R. (2001) Economic Weeding Method for Irrigated Rice Production in Bangladesh. Agricultural Water Management, 46, 267-276.

[9] Dass, A., Shekhawat, K., Choudhary, A.K., Sepat, S., Rathore, S.S., Mahajan, G. and Chauhan, B.S. (2017) Weed Management in Rice Using Crop Competition-A Review. Crop Protection, 95, 45-52. https://doi.org/10.1016/j.cropro.2016.08.005

[10] Linquist, B., Snyder, R., Anderson, F., Espino, L., Inglese, G., Marras, S., Russo, A., et al. (2015) Water Balances and Evapotranspiration in Water- and Dry-Seeded Rice Systems. Irrigation Science, 33, 375-385. https://doi.org/10.1007/s00271-015-0474-4

[11] Price, A.J., Kelton, J. and Mosjidis, J. (2012) Utilization of Sunn Hemp for Cover Crops and Weed Control in Temperate Climates. In: Price, A.J., Ed., Weed Control, InTech.

https://www.intechopen.com/books/weed-control/utilization-of-sunn-hemp-for-co ver-crops-and-weed-control-in-temperate-climates

[12] Fonseca, W.L., de Oliveira Sousa, T., dos Santos, A.S., da Silva Oliveira, J.B., Pacheco, L.P., de Castro Medeiros, L. and de Almeida, F.A. (2016) Influence of Different Cover Crops on the Emergence and Development of 'Digitariahorizontalis'. Australian Journal of Crop Science, 10, 1244. https://doi.org/10.21475/ajcs.2016.10.09.p7624

[13] Hayden, Z.D., Brainard, D.C., Henshaw, B. and Ngouajio, M. (2012) Winter Annual Weed Suppression in Rye-Vetch Cover Crop Mixtures. Weed Technology, 26, 818-825. https://doi.org/10.1614/WT-D-12-00084.1

[14] Buchanan, A.L., Kolb, L.N. and Hooks, C.R. (2016) Can Winter Cover Crops Influence Weed Density and Diversity in a Reduced Tillage Vegetable System? Crop Protection, 90, 9-16. https://doi.org/10.1016/j.cropro.2016.08.006

[15] Masilionyte, L., Maiksteniene, S., Kriauciuniene, Z., Jablonskyte-Rasce, D., Zou, L. and Sarauskis, E. (2017) Effect of Cover Crops in Smothering Weeds and Volunteer Plants in Alternative Farming Systems. Crop Protection, 91, 74-81.

https://doi.org/10.1016/j.cropro.2016.09.016

[16] White, C.A., Holmes, H.F., Morris, N.L. and Stobart, R.M. (2016) A Review of the Benefits, Optimal Crop Management Practices and Knowledge Gaps Associated with Different Coper Crop Species. AHDB. Cereals and Oilseeds Research Review. Research Review No. 90.

https://cereals.ahdb.org.uk/publications/2016/december/19/a-review-of-the-benefits ,-optimal-crop-management-practices-and-knowledge-gaps-associated-with-differe nt-cover-crop-species.aspx

[17] Teasdale, J.R. (1996) Contribution of Cover Crops to Weed Management in Sustainable Agricultural Systems. Journal of Production Agriculture, 9, 475-479. https://doi.org/10.2134/jpa1996.0475

[18] Reddy, K.N. (2001) Effects of Cereal and Legume Cover Crop Residues on Weeds, Yield, and Net Return in Soybean (Glycine max). Weed Technology, 15, 660-668. https://doi.org/10.1614/0890-037X(2001)015[0660:EOCALC]2.0.CO;2

[19] Cherr, C.M., Scholberg, J.M.S. and McSorley, R. (2006) Green Manure as Nitrogen Source for Sweet Corn in a Warm-Temperate Environment. Agronomy Journal, 98, 1173-1180. https://doi.org/10.2134/agronj2005.0036

[20] Teasdale, J.R. and Mohler, C.L. (1993) Light Transmittance, Soil Temperature, and Soil Moisture under Residue of Hairy Vetch and Rye. Agronomy Journal, 85, 673-680. https://doi.org/10.2134/agronj1993.00021962008500030029x 
[21] Moody, K., De Datta, S.K., Bhan, V.M. and Manna, G.B. (1986) Weed Control in Rainfed Lowland Rice. In: Progressin Rainfed Lowland Rice, IRRI, Philippines, 359-370.

[22] Sahid, I.B. and Hossain, M.S. (1995) The Effects of Flooding and Sowing Depth on the Survival and Growth of Five Rice-Weed Species. Plant Protection Quarterly, 10, 139-142.

[23] Oluyemi, A.T. (2014) Characterisation of Jasmine 85 Rice (Oryza sativa) Variety from Different Sources of Seed Production in Ghana. Doctoral Dissertation, Kwame Nkrumah University of Science and Technology, Kumasi.

[24] Gealy, D.R. and Yan, W. (2012) Weed Suppression Potential of 'Rondo' and Other Indica Rice Germplasm Lines. Weed Technology, 26, 517-524.

https://doi.org/10.1614/WT-D-11-00141.1 